\title{
PRIORITAS MASALAH DIARE PADA BALITA AKIBAT KURANGNYA PENGETAHUAN IBU TERHADAP PENYAKIT DIARE DI KELURAHAN MANDALIKA TAHUN 2017
}

\author{
Deny Sutrisna Wiatma*, Suci Nirmala** \\ Fakultas Kedokteran Universitas Islam Al-Azhar \\ Jl. Unizar No.20 Turida Mataram \\ denz.louhan@gmail.com
}

\begin{abstract}
ABSTRAK
Di Puskesmas Cakra negara terdapat 4 masalah tersering yang terjadi di kelurahan Bertais yaitu, ISPA, Diare, Demam Berdarah dan cakupan imunisasi yang rendah. Mengetahui akar permasalah diare yaitu kurangnya pengetahuan masyrakat terhadap pentingnya kebersihan, dengan metode Delbeecq yatiu penentuan prioritas masalah dalam komunitas tampa melakukan diskusi antar anggota, sehingga diperoleh akar penybab dari diare adalah kurangnya pengetahuan masyrakat terhadap pentingnya kebersihan. Kesimpilan : Masalah kesehatan di Basretais yang prioritas adalah diare pada balita yang dipengaruhi oleh pengetahuan ibu tentang diare.
\end{abstract}

Keyword : Diare, Bertais, Pengetahuan Ibu.

\section{PENDAHULUAN}

Kelurahan Bertais memiliki 6 Lingkungan yaitu, Gontoran Barat, Pengempel Indah, Karang Rundun, Bertais Daye, Bertais Selatan, dan Butun Indah. Menurut data dari Puskesmas Cakranegara terdapat 4 masalah tersering yang terjadi di kelurahan Bertais yaitu, ISPA, Diare, Demam Berdarah dan cakupan imunisasi yang rendah. Setelah dilakukan penentuan prioritas masalah secara voting maka masyarakat kelurahan bertais terbanyak memilih masalah diare.

Menurut data WHO dan UNICEF yang dikutip oleh Michael Farthing dalam Jurnal Clinical Gastroenterology, kejadian diare di seluruh dunia mencapai 2 milyar kasus per tahun, dan di Negara berkembang, 1,9 miliyar anak dibawah usia 5 tahun menderita diare setiap tahunnya. Sebanyak $18 \%$ diantaranya mengalami kematian, ini berarti lebih dari 5000 anak dibawah usia 5 tahun meninggal setiap harinya karena kasus diare. Dari seluruh kejadian kematian akibat diare, $78 \%$ diantaranya terjadi di Afrika dan Asia Tenggara.

Berdasarkan data Riskesdas tahun 2013 angka period prevalence diare di ndonesia sebesar 3,5\%. Angka ini menurun dari Riskesdas sebelumnya tahun 2007, yaitu sebesar 9\%. Insiden diare pada balita di Indonesia pada tahun 2013 adalah sebesar 6,7\%. Berdasarkan karakteristik penduduk, persentase insiden diare pada kelompok umur balita sebesar $6,7 \%$ dan pada kelompok bayi sebesar 7,0\%. Angka ini menunjukkan balita menempati urutan kedua sebagai kelompok umur yang rentan terkena diare. Angka prevalensi diare di Jawa Timur tahun 2007 sebesar 7,8\%, dan angka prevalensi diare pada balita sebesar 16,7\% (Riskesdas, 2007). Angka 

tahun 2013. diskusi.

\begin{tabular}{|l|c|c|c|c|c|c|}
\hline \multicolumn{1}{|c|}{ Lasalah } & $\begin{array}{c}\text { Karang } \\
\text { Rundun }\end{array}$ & $\begin{array}{c}\text { Butun } \\
\text { Indah }\end{array}$ & $\begin{array}{c}\text { Gontoran } \\
\text { Barat }\end{array}$ & $\begin{array}{c}\text { Pengempel } \\
\text { Indah }\end{array}$ & $\begin{array}{c}\text { Bertais } \\
\text { Selatan }\end{array}$ & $\begin{array}{c}\text { Bertais } \\
\text { Daya }\end{array}$ \\
\hline $\begin{array}{l}\text { DIARE PADA } \\
\text { BALITA }\end{array}$ & 6 & 7 & 4 & 7 & 4 & 4 \\
\hline ISPA & 2 & 3 & 3 & 1 & 4 & 3 \\
\hline DBD & - & - & 1 & 7 & - & - \\
\hline $\begin{array}{l}\text { CAKUPAN } \\
\text { IMUNISASI }\end{array}$ & 4 & 1 & - & - & - & - \\
\hline
\end{tabular}

Data Kemenkes di wilayah NTB

2013 mencatat kasus diare di Kota

Mataram sebesar 104,06\% meningkat

bila dibandingkan dengan tahun 2012

yaitu 54,90\%.

Persentase penemuan kasus diare tertinggi tercatat di Puskesmas Karang Taliwang $(192,91 \%)$ dan yang terendah di Puskesmas Dasan Agung (44,07\%). Kasus diare yang tercatat di kelurahan Bertais mengalami fase naik dan turun dimana pada tahun 2015 tercatat kasus terendah yaitu 25 kasus pada bulan Maret dan kasus tertinggi terjadi pada bulan Desember 2015 yaitu 64 kasus.

\section{PRIORITAS MASALAH}

Penentuan prioritas masalah yang terjadi di Kelurahan Bertais dilakukan dengan menggunakan Metode Delbeecq. Metode Delbeecq adalah metode penentuan prioritas masalah dalam komunitas yang dilakukan tanpa diskusi antar anggotanya melainkan ditentukan secara voting. Hal ini dilakukan karena dalam metode ini tidak diperlukan kesamaan derajat pendidikan sehingga
Setelah dilakukan voting pada masyarakat Kelurahan Bertais, maka ditemukan hasil yaitu :

Tabel 1. Hasil Voting Prioritas Masalah Berdasarkan hasil voting di atas, maka didapatkan hasil prioritas masalah adalah Diare pada balita.

\section{ANALISA PENYEBAB MASALAH}

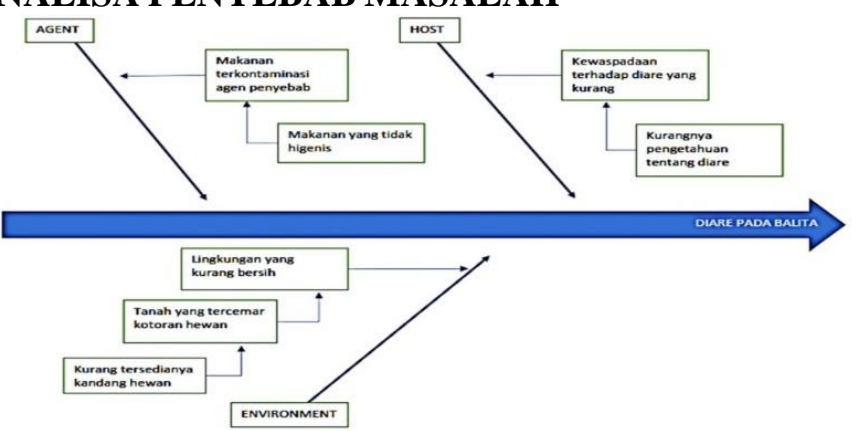

Bagan 3. Fish Bone

\section{ALTERNATIF \\ PEMECAHAN \\ MASALAH}

Berdasarkan dari hasil wawancara dengan menggunakan kuesioner pada masyarakat di Kelurahan Bertais, kami menyimpulkan bahwa penyebab dari akar masalah Diare adalah Kurangnya pengetahuan masyarakat terhadap pentingnya kebersihan, maka alternatif 
pemecahan masalah yang akan kami lakukan yaitu dengan melakukan penyuluhan kesehatan kepada masyarakat di Kelurahan Bertais.

\section{PROGRAM KEGIATAN}

\section{INTERVENSI KESEHATAN}

Progran kegiatan intervensi kesehatan yang dilakukan berupa penyuluhan kesehatan tentang diare. Penyuluhan ini dilakukan oleh kelompok KKL KESMAS Fakultas Kedokteran Universitas Islam Al-Azhar yang bertugas di Kelurahan Bertais. Penyampaian materi dilakukan oleh Pemateri secara sederhana menggunakan bahasa yang mudah dipahami oleh para peserta.

Penyuluhan dilaksanakan dengan mengumpulkan 50 peserta ibu-ibu di Lingkungan Gontoran Barat, dilakukan pada hari Senin, 14 Agustus 2017 pukul 14.00 WITA. Penyuluhan dilakukan secara singkat dan padat, dengan penyampaian materi diare.

Menyampaikan pemahaman tentang diare, apa itu diare, apa saja penyebab diare, cara membedakan penyebab diare dilihat dari jenis $\mathrm{BAB}$ nya, pertolongan pertama, pengobatan, sampai pencegahan untuk diare.
PEMBAHASAN

INTERVENSI

KESEHATAN

Penyuluhan dilakukan karena melihat perlunya pembinaan pada masyarakat mengenai apa itu diare, apa saja penyebab diare, cara membedakan penyebab diare dilihat dari jenis $B A B$ nya, pertolongan pertama, pengobatan, sampai pencegahan untuk diare

Penyuluhan tentang diare dipilih karena masih banyaknya masyarakat yang kurang memahami tentang hal tersebut, dan diharapkan dengan dilakukannya penyuluhan pada peserta, nantinya dapat membantu menyebarkan informasi dan edukasi pada masyarakat luas.

\section{MONITORING}

Penyuluhan berjalan lancar dan cukup baik walaupun di tempat yang sederhana. Peserta penyuluhan menyimak penjelasan dari pemateri dengan khidmat. Pada saat sesi tanya jawab penyuluhan, respon warga cukup baik bila dilihat dari jumlah warga yang ingin menjawab pertanyaan. Penyuluhan yang kami lakukan pada hari Senin tanggal 14 Agustus 2017, ada sekitar 47 orang ibu dan anak dari 50 orang sasaran yang mengikuti penyuluhan dengan dihadiri oleh kepala Lurah beserta kepala lingkungan Gontoran Barat berjalan dengan baik dengan diakhiri pembagian doorprize untuk warga yang beruntung. 
EVALUASI

Acara dimulai tidak sesuai dengan jadwal yang direncanakan sebelumnya akibat dari misscommunication antara panitia dengan pihak Kelurahan.

\section{KESIMPULAN}

Dari hasil KKL-Kesmas yang dilakukan oleh kelompok kami, maka kami menemukan bahwa masalah kesehatan yang menjadi prioritas utama di Kelurahan Bertais adalah diare pada balita, dimana hal itu utamanya dipengaruhi oleh pengetahuan ibu yang masih kurang akan diare. Maka dari itu kelompok kami juga telah melakukan intervensi untuk mengatasi masalah tersebut yaitu dengan melakukan penyuluhan tentang diare.

\section{DAFTAR PUSTAKA}

Fatching Michael. 2013. Acute Diarrhea in Adults and Children: A Global Perspective.United Kingdom: Journal of Clinical Gastroenterology: January 2013 Volume 47 - Issue 1 - p 12-20. http://journals.lww.com/jcge/Fullte xt/2013/01000/Acute Diarrhea in Adults and Children A_Global.7.aspx Diunduh pada 3 Agustus 2017.

Adyanasari, Festy. 2012. Etiologi dan Gambaran Klinis Diare Akut di RSUP Dr Kariadi Semarang. Semarang. Diunduh di http://eprints.undip.ac.id.Festy Adyanastri.pdf/ pada 3 Agustus 2017.
Kliegman,R.M.,Marcdante,K.J.,Jenson,H. B., Behrman, R.E.,2006. Nelson Essential of Pediatrics. Elseivier Saunders, Philadelphia

Tanto, Chris.2014. Kapita Selekta Kedokteran. Jakarta. Meida Aesculapius.

Kemenkes RI. 2011. Buletin Jendela Data dan Informasi Kesehatan Volume 2 Triwulan 2. Jakarta

Suharyono. 1986. Diare Akut. Lembaga Penerbit Fakultas Ekonomi Universitas Indonesia. Jakarta. 